\title{
Les oiseaux du Cambodge : classifications populaires et valeurs sociales
}

\section{Marie Alexandrine Martin}

\section{(2) OpenEdition \\ 1 Journals}

Édition électronique

URL : https://journals.openedition.org/tc/428

DOI : $10.4000 /$ tc. 428

ISSN : 1952-420X

Éditeur

Éditions de l'EHESS

\section{Édition imprimée}

Date de publication : 1 octobre 1998

ISSN : 0248-6016

\section{Référence électronique}

Marie Alexandrine Martin, «Les oiseaux du Cambodge : classifications populaires et valeurs sociales », Techniques \& Culture [En ligne], 30 | 1998, mis en ligne le 28 octobre 2005, consulté le 29 septembre 2022. URL : http://journals.openedition.org/tc/428 ; DOI : https://doi.org/10.4000/tc.428

Ce document a été généré automatiquement le 29 septembre 2022.

Tous droits réservés 
Les oiseaux du Cambodge : classifications populaires et valeurs sociales

Marie Alexandrine Martin 